\title{
Growth Curves of Turkish Saanen Goats’ Kids Grouped for Weight and Body Mass Index
}

\begin{abstract}
Growth curves and weaning stress differences were investigated in Turkish Saanen kids grouped for their weight and Body Mass Index $\left(\mathrm{BMI}=\right.$ weight/height $\left.{ }^{2}\right)$. Data included 884 records collected from 61 Turkish Saanen kids raised in Canakkale, Turkey. Slopes were calculated for each kid and were analyzed as data using ordinary least squares, and repeated weights for each kid were analyzed using various covariance structures. Differences between male and female kids were small and non-significant before weaning $(P=0.55)$, while larger $(P=0.06)$ after weaning. Heavy animals grew faster than light animals before weaning $(\mathrm{P}<0.01)$ but lost their advantage after weaning $(\mathrm{P}>0.05)$. Fat animals (high BMI) grew faster than lean animals (low BMI) before weaning $(\mathrm{P}<$ $0.01)$ while the differences slightly diminished after weaning $(\mathrm{P}=0.04)$. This may be because light and lean kids were not affected from the weaning shock as much as the heavy and fat kids, which had stuttered growth after weaning. Fit statistics indicated that first-order ante dependence was the best fit covariance structure for these data. Analyses specifying random model and covariance structures did not have an advantage over an approach where slopes were manually calculated and analyzed as data using ordinary least squares.
\end{abstract}

Key Words: turkish Saanen goats, growth curves, repeated data, slopes, covariance structures

\section{Zusammenfassung}

Titel der Arbeit: Wachstumskurven von unterschiedlichen Lebensgewicht- und KörpermasseindexGruppen bei türkischen Saanen Ziegenlämmern

Die Wachstumskurven und der Absetzstress wurden bei türkischen Saanen Ziegenlämmern untersucht, aufgeteilt in Gewichts- und Körpermasseindexgruppen (BMI=Lebendgewicht/Widerristhöhe ${ }^{2}$ ). Einbezogen wurden 884 Lebendgewichtdaten von 61 Ziegen des Versuchsbetriebes der Canakkale Universität. Die Regressionskoeffizienten von Lebendgewichtsdaten der einzelnen Tiere wurden mit unterschiedlichen statistischen Methoden, die Unterschiede in ihrer Kovarianzstruktur aufwiesen, analysiert. Bei den Regressionskoeffizienten wurden vor dem Absetzen im Gegensatz zu der Zeit nach dem Absetzen zwischen den Geschlechtern nicht signifikante geringe Unterschiede festgestellt $(\mathrm{P}=>0,05)$. Vor dem Absetzen wuchsen die fetteren, schwereren Tiere (höheren $\mathrm{BMI})$ schneller als die magereren, leichteren $(\mathrm{P}=<0,01)$. Nach dem Absetzen verringerten sich diese Unterschiede signifikant zwischen den schweren und leichten bzw. fetten und mageren Tieren. Obwohl sich die Werte der Regressionskoeffizienten nach dem Absetzen in allen Gruppen verringern, sind die Unterschiede bei den schweren d. h. fetteren Tieren zwischen der Zeit vor bzw. nach dem Absetzen größer als bei den leichteren Tieren. Für die analysierten Daten zeigte die "first-order ante dependence" Kovarianzstruktur die besten Anpassungsparameter. Die Analysen, welche spezifische Modell- und Kovarianzstrukturen hatten, zeigten keinen Vorteil gegenüber den vorgenannten, wobei die Regressionskurven manuell errechnet und mit der üblichen Methode der kleinsten Quadrate analysiert wurden.

Schlüsselwörter: Türkische Saanen Ziegenlämmer, Wachstumskurven, wiederholte Daten, Regressionskoeffizienten, Kovarianzstrukturen

\section{Introduction}

Dairy goats are capable of supplying their kids with enough milk to satisfy growth performances, even under conditions below the optimum (SNELL and TAWFIK, 1999). Growth curves of goat kids may have significant deviations during weaning, which may be called a stressful event. Magnitude of the stress depends on age and 
weight of the kids (MORAND et al., 1982). Heavy and light kids or male and female kids may react to weaning in different ways. Over-conditioned, or high BMI (Body Mass Index) kids may suffer more from weaning stress while leaner animals may be less sensitive to the effects of weaning. RINGDORFER (2001) reported that heavy kids had higher levels of kidney fat than light kids in Boer $\mathrm{x}$ Saanen kids. STEINHARDT and THIELSCHER (2004) reported that male and female calves had different growth curves and inter- and intraindividual variation were greater when calves were in 1 to 10 days old compared to the later age calves.

Indigenous goat breeds are able to thrive with minimum inputs (LEBBIE, 2004). Though not an indigenous breed, Saanen kids that are lighter before weaning may perform a compensatory growth after weaning and offset the slower weight gain. Ugur et al. (2004) reported that Turkish Saanen kids that are weaned at different ages and had significantly different weights at weaning approached similar weights $(P>0.05)$ at 3 months of age. SAMPELAYO (2003) reported similar as TOUKOUROU and PETERS (1999) that kids with restricted milk replacer intake had compensatory growth later with a reduction in energy requirements for maintenance.

NAGPAL et al. (1995) wrote that in their study, late weaning (90 days) was more expensive compared to earlier weaning (60 days) and early weaning resulted in surplus milk of 12,7 to $22,5 \mathrm{~kg}$. There are not enough studies in literature to determine an optimum weight at weaning. PALMA and GALINA (1995) reported that weaning kids at $10 \mathrm{~kg}$ had no significant effects on their breeding age and they could kid at 13-14 months of age just like the kids weaned at $15 \mathrm{~kg}$. MORAND et al. (1982) wrote that weaning at $10 \mathrm{~kg}$ and $8.5 \mathrm{~kg}$ did not delay the growth while weaning shock was significant when the kids were weaned at $7 \mathrm{~kg}$.

Major purpose of this study was to investigate the differences between growth curves of Turkish Saanen kids in different time periods. Effects of sex, weight classes (heavy or light) and BMI (Body Mass Index) values (fat or lean) on growth curves were investigated before weaning, after weaning and for the whole period. Investigating these effects may provide evidence on weaning stress and compensatory gain of Turkish Saanen kids.

Methods to analyze repeated data were compared to investigate whether simpler methods provide similar answers. Using slopes as data and using weights and fitting a variance-covariance model to account for correlations arising from individual kids were compared to study whether these two methods change the rank of the major groups. In addition, correlations between slopes before weaning and slopes after weaning were calculated.

\section{Materials and Methods}

Data included 884 records collected on 61 Turkish Saanen kids raised in Uvecik Research Center, Canakkale, Turkey. The kids had access to standard kid rations and alfalfa hay as early as three days. After three days with the kids, dams were taken out to the pasture during the day. Kids were allowed to suckle their dams at night. Weaning age ranged from 36 to $42 \mathrm{~d}$. After weaning, they were gradually allowed on pasture.

Animals were divided into two weight groups at weaning. Animals heavier than $10 \mathrm{~kg}$ were included in the "heavy" group and those weighing equal to or lighter than $10 \mathrm{~kg}$ were included in the "light" group of animals because $10 \mathrm{~kg}$ was the mean value of the 
kids at weaning. Heavy and light animals were the two levels of a variable called "weight-class". Effects of Body Mass Index (BMI= weaning weight/cidago height ${ }^{2}$ ) on slopes were investigated as well. In analyses including BMI, animals were divided into two groups. Animals were classified "fat" if their BMI value was larger than 0.06 and they were classified "lean" if the BMI value was smaller than or equal to 0.06 because 0.06 was the mean BMI value of the kids at weaning. All the models included slopes as the dependent variable. The only exclusion was the model where ante-dependence covariance structure was fit; which used weights instead of the slopes as observations.

Statistical model used was:

$\mathrm{Y}_{\text {iklmnopr }}=\mu+\mathrm{A}_{\mathrm{i}}+\mathrm{B}_{\mathrm{k}}+\mathrm{C}_{\mathrm{l}}+\mathrm{D}_{\mathrm{m}}+\mathrm{E}_{\mathrm{n}}+\mathrm{F}_{\mathrm{o}}+\mathrm{G}_{\mathrm{p}}+\mathrm{H}_{\mathrm{r}}+\mathrm{e}_{\mathrm{iklmnopr}}$

where;

$\mathrm{Y}_{\text {iklmnopr }}=$ individual slopes calculated from regression of weight on age and individual observations for weight.

$A_{i}=$ fixed effect due to birth type (single, twin),

$B_{k}=$ fixed effect due to age of dam (young, old),

$\mathrm{C}_{\mathrm{l}}$ = fixed effect due to weight class of kid or BMI at weaning (light, heavy or lean, fat),

$\mathrm{D}_{\mathrm{m}}=$ fixed effect due to gender of kid (female, male),

$\mathrm{E}_{\mathrm{n}}=$ fixed effect due to period (before weaning, after weaning),

$\mathrm{F}_{\mathrm{o}}=$ covariate, birth weight,

$G_{p}=$ covariate, amount of milk the kids consume in their first control

$\mathrm{H}_{\mathrm{r}}=$ repeated effect of the subject (all animals),

$\mathrm{e}_{\mathrm{iklmnopr}}=$ random element assumed to be normally and independently distributed with mean of zero and variance $\sigma^{2}$.

The error term was not assumed to be independently distributed when weights were used as the dependent variable; this assumption was made only for the case when slopes were used as the dependent variable. A full model and a reduced model were fit to analyze the slopes. The full model included effects of the period before weaning and the period after weaning. Effects of the variable 'period' were excluded in the reduced model to investigate overall effects of the other variables on slopes without adjusting for the period effect. $\mathrm{H}_{\mathrm{r}}$ was in the model only for the repeated analyses and was not included for the slopes analyses. Two way and three way interactions were included in the model and those non-significant were deleted.

All analyses using slopes as the dependent variable were carried out using the same model while one model included BMI instead of the weight-class. Regression lines were fit for each animal using proc REG of SAS V8 and slopes were analyzed using proc MIXED in SAS V8 (SAS Institute Inc., 1999).

Using a second approach, repeated statement in proc MIXED was used to fit a growth curve model for heavy and light animals as well as a variance-covariance model to account for correlations of all the observations arising from individual kids (JENNRICH and SCHLUCHTER, 1986; EVERITT, 1995). Different covariance structures (JENNRICH and SCHLUCHTER, 1986; WOLFINGER, 1996) were examined to fit the best model. Akaike's Information Criteria (AKAIKE, 1974) and Schwarz's Bayesian Criteria (SCHWARZ, 1978) associated with the models are given 
in Table 1. Among those, ante-dependence model had the highest Akaike's Information Criteria and Schwarz’s Bayesian Criteria.

Table 1

Akaike’s Information Criteria (AIC) and Schwarz’s Bayesian Criteria (SBC) for different covariance structures (Akaike’s Informationskriterien und Schwarz’s Bayesian Kriterien für unterschiedliche Kovarianzstrukturen)

\begin{tabular}{lll}
\hline & \multicolumn{2}{l}{ Fit statistics } \\
\cline { 2 - 3 } Covariance Structure & AIC & SBC \\
\hline Compound Symmetry & -1763.9 & -1765.9 \\
Heterogenous Compound Symmetry & -1467.4 & -1485.0 \\
Auto Regressive & -1321.1 & -1323.0 \\
First-order Heterogenous Auto Regressive & -1132.1 & -1149.6 \\
First-order Autoregressive Moving-Average & -1314.6 & -1317.6 \\
First-order Ante-dependence & -1112.1 & -1144.3 \\
First-order Factor Analytic & -1394.5 & -1426.7 \\
First-order Unstructured & -1700.0 & -1716.6 \\
Huynh-Feldt & -1731.9 & -1749.4 \\
Toeplitz & -1308.0 & -1324.6 \\
First-order Heterogenous Toeplitz & -1700.0 & -1716.6 \\
Variance Components & -1896.9 & -1897.9 \\
\hline
\end{tabular}

First-order ante-dependence (KENWARD, 1987; PATEL, 1991; MACCHIAVELLI and ARNOLD, 1994) was used to build the covariance structure of the kid blocks in R matrix because ante-dependence structure resulted in the highest fit statistics (Table 1). Elements (i)j ${ }^{\text {th }}$ of the covariance structure are given in equation 1 , where $\sigma_{i}^{2}$ is the $i^{\text {th }}$ variance parameter, and $\mathrm{P}_{\mathrm{k}}$ is the $k^{\text {th }}$ autocorrelation parameter satisfying $\left|\mathrm{P}_{\mathrm{k}}\right|<1$.

Equation 1: $\sigma_{\mathrm{i}} \sigma_{\mathrm{j}} \prod_{k=i}^{j-1} p_{\mathrm{k}}$

In analyses with the repeated statement, heterogeneity of the slopes was tested by including age in the model. In the same model, weight-classes were included to request a different intercept for heavy and light animals, and interaction of weightclass by age was included to make the slopes different over time for heavy and light animals. The null model likelihood ratio test (LRT) was performed to decide if the ante-dependence matrix would be preferred over the diagonal one of the ordinary least-squares null model.

\section{Results}

Coefficients of determination in linear and quadratic models for animals grouped for their weights are given in Table 2. Overall, quadratic effects were significant while adding the quadratic term to the model increased the coefficient of determination for one percent, from 0.97 to 0.98 . Analysis using the data set composed of heavy animals showed the same trend. Quadratic effects were significant while including the quadratic effects increased the coefficient of determination for only one percent, from 0.97 to 0.98 . However, in the data set composed of light animals, adding quadratic effects resulted in an increase of 3 percent, from 0.95 to 0.98 . Mean weight for the kids was $10 \mathrm{~kg}$ at weaning, and 10-kg animals tended to stay closer to the linear line more than heavy and light group of animals (Figure).

Interclass correlations between the time periods were calculated for heavy and light animals. The correlation between slopes before weaning and after weaning was 0.28 (P $=0.12)$ for light animals while that for heavy animals was $0.09(\mathrm{P}=0.28)$. 
Table 2

Coefficient of Determination in linear and quadratic models for animals grouped for their weight. (Determinationskoeffizient bei linearen und quadratischen Modellen für Gewichtsklassengruppen)

\begin{tabular}{lll}
\hline & Effects & \\
\cline { 2 - 3 } Weight groups & Linear & Quadratic \\
\hline Overall & 0.97 & 0.98 \\
Light & 0.95 & 0.98 \\
Heavy & 0.97 & 0.98 \\
\hline
\end{tabular}

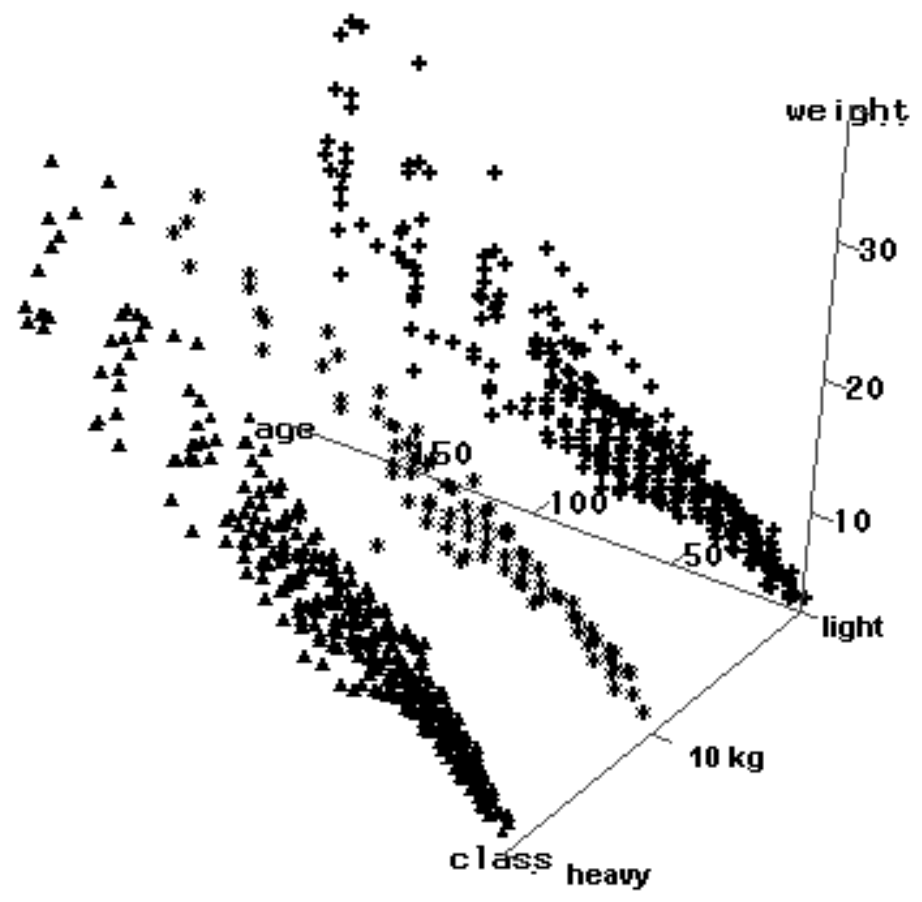

Fig.: Growth curves of animals, heavy, light or $10 \mathrm{~kg}$ at weaning (Wachstumskurven der schweren, leichten und der über $10 \mathrm{~kg}$ schweren Tiere beim Absetzen)

\section{Full model}

Differences between male and female kids were small and non significant before weaning $(\mathrm{P}>0.55)$, while larger $(\mathrm{P}=0.06)$ after weaning (Table 3$)$. Though the differences were non-significant, females had steeper growth curves compared to males before weaning while they lost their advantage and had a more gradual growth curve after weaning. Differences between the slopes before weaning and after weaning were large $(\mathrm{P}<0.05)$ for both males and females.

\section{Table 3}

Least squares means for slopes for heavy and light animals and males and females in different time periods (LSMittelwerte der Regressionskoeffizenten für schwere und leichte bzw. männliche und weibliche Tiere in unterschiedlichen Perioden)

\begin{tabular}{lll|lll}
\hline & \multicolumn{3}{l}{ Slopes } & & \\
\cline { 2 - 6 } Time period & Light & Heavy & Female & Male & SE $^{\mathrm{a}}$ \\
\hline Before weaning & $0.14^{\mathrm{b}}$ & $0.21^{\mathrm{d}}$ & $0.18^{\mathrm{b}}$ & $0.17^{\mathrm{b}}$ & 0.01 \\
After weaning & $0.10^{\mathrm{c}}$ & $0.12^{\mathrm{c}}$ & $0.10^{\mathrm{c}}$ & $0.12^{\mathrm{c}}$ & 0.01 \\
\hline
\end{tabular}

${ }^{\mathrm{a}}$ Pooled standard error based on most conservative number in a row.

${ }^{\mathrm{b}, \mathrm{c}, \mathrm{d}}$ Row and Column values with different superscripts differ $(P<.05)$.

Effects of weight groups on growth curves were investigated (Table 3). Slopes before weaning and slopes after weaning were calculated for each kid and were compared for 
different weight classes. Overall, heavy animals had steeper slopes (0.17) than light animals $(0.11)$ and the differences were large $(\mathrm{P}<0.01)$. The kids had steeper slopes before weaning (0.18) compared to the slopes after weaning $(0.11)$ and the differences were large $(\mathrm{P}<0.01)$.

Heavy kids had steeper growth curves than light kids before weaning $(\mathrm{P}<0.01)$ while the differences were lost after weaning $(\mathrm{P}>0.05$, Table 3$)$. Though heavy kids seem to be growing at a higher pace than light kids after weaning (0.12 versus 0.10$)$, differences were not significant. Effects of birth weight on the growth curves were small $(\mathrm{P}>0.10)$ while effects of dam milk were large $(\mathrm{P}<0.05)$.

Effects of Body Mass Index (BMI) on slopes were investigated (Table 4). Effects of BMI on slopes were large $(\mathrm{P}<0.01)$. As the ratio weaning weight/cidago height ${ }^{2}$ increased, the kids grew faster, while higher height ${ }^{2}$ of kids compared to their weights resulted in slower growth curves. Kids in the "fat" group had higher slopes (0.17) than the kids in the "lean" group (0.13) and the differences were large $(\mathrm{P}<0.01)$. Fat kids had steeper growth curves than lean kids before weaning $(\mathrm{P}<0.01)$. While the differences were significant after weaning also $(P=0.04)$, they became smaller.

Table 4

Least squares means for slopes for lean and fat animals in different time periods (LS-Mittelwerte der Regressionskoeffizenten für magere und fette Tiere in unterschiedlichen Perioden)

\begin{tabular}{llll}
\hline & \multicolumn{2}{c}{ Slopes } & SE $^{\mathrm{a}}$ \\
\cline { 2 - 4 } Time period & Lean & Fat & 0.01 \\
\hline Before weaning & $0.16^{\mathrm{b}}$ & $0.20^{\mathrm{d}}$ & 0.01 \\
After weaning & $0.10^{\mathrm{c}}$ & $0.13^{\mathrm{e}}$ & \\
\hline a Pooled standard error based on most conservative number in a row. & & \\
b,c,der Row and Column values with different superscripts differ $(P<.05)$. & &
\end{tabular}

\section{Reduced model}

Effects of the variable 'period' were excluded in the reduced model to investigate overall effects of the other variables on slopes. In the reduced model where one slope was calculated for each animal, differences between heavy and light animals were highly significant while all the other effects were nonsignificant. Heavy animals tended to grow faster than light animals just as in the full model. However, because no adjustments were made for the period effect and because a more general slope was fit for the whole growth period, slopes were much more gradual for all animals compared to the first period of the full model. For heavy animals, least squares means of the slopes was 0.13 versus 0.17 of the full model. For light animals, slopes were 0.10 versus 0.11 of the full model.

\section{Repeated statement analyses}

In addition to the manual slopes analyses that removes $G, R$ and $\mathrm{Z}$ matrices from a usual repeated model; repeated statement in proc MIXED of SAS V8 (SAS Institute Inc. 1999) was used to analyze the repeated weights using ante-dependence covariance structure. Akaike's Information Criteria (AKAIKE, 1974) and Schwarz's Bayesian Criteria (SCHWARZ, 1978) associated with the models showed that first order antedependence covariance structure was the best fit for this data because values of these statistics were highest among all the others (Table 1). Because they all had negative values, the values closest to zero indicates the best fit. The null model likelihood ratio test (LRT) was highly significant for this model (chi-square value of 1634 with 32 
degrees of freedom), indicating that the ante-dependence covariance matrix is preferred over the diagonal one of the ordinary least-squares null model.

An overall growth curve accounting for possible heterogeneous slopes was tested by including age in the model, and it cannot be rejected from these data $(\mathrm{P}>0.10)$. Weight classes of the kids were included to test the null hypothesis of a common intercept, and this hypothesis was highly significant. Testing slopes in time (age by weight class interaction) showed that slopes of heavy and light animals were significantly different at the $2 \%$ level.

\section{Discussion}

Coefficients of determination in linear and quadratic models for animals grouped for their weights indicated that light kids deviated more from linearity compared with heavy kids. Interclass correlations of slopes before weaning and slopes after weaning were greater for light animals and smaller for heavy animals though the correlations were non-significant. YAN et al. (1993) reported that weaning after 39 days, as opposed to 28 days, significantly reduced the total intake of concentrate in male Saanen kids.

In the full model, females lost their advantage after weaning, which means that male kids may be more resistant to the stress of weaning. In contrast, FEHR and SAUVANT (1976) reported that females were more resistant to weaning stress.

Heavy kids had steeper growth curves than light kids before weaning $(P<0.01)$ while the differences were lost after weaning $(\mathrm{P}>0.05)$. The reason differences between heavy and light kids were lost after weaning may be because light kids were not affected from the weaning shock as much as the heavy kids, which had stuttered growth after weaning. The differences between heavy and light kids probably arise due to milk of the dams. Kids growing at different paces due to the effects of dam milk may form a more homogenous population after weaning due to standard feeding.

General tendency in the results of the BMI classification were similar to those of the weight classification. However, the differences were significant in BMI classification after weaning, while they were small enough to be non-significant in weight classification. Both models used the same variables and the same methods for analyses; the only difference was one of the models used weight classification while the other used BMI classification. Heavy animals were not necessarily in the fat animal group; some of them were in the lean group due to their "tall" nature (higher cidago). RINGDORFER (2001) reported that heavy kids had higher levels of kidney fat than light kids and had higher fat content in shoulder and legs.

When going from full model to the reduced model, slopes of heavy animals decreased greatly while those of light animals were not affected as much as the heavy animals. Because the full model included time periods (slopes were adjusted for the period effect) and the reduced model did not, it can be stated that effects of the time period (before weaning and after weaning) adversely affected heavy animals while light animals were affected less by the weaning stress.

Analyses using the ante-dependence covariance structure gave similar results both to the reduced model and to the full model. Fit statistics such as AIC and SBC and null model likelihood ratio test measured fit of the ante-dependence model versus diagonal one of the ordinary least squares when weights were used as the dependent variable. In 
the reduced and full models, slopes were calculated and analyzed instead of weights. The full model included effects of the time period while the reduced model did not.

Fit statistics showed an advantage of ante-dependence and many other covariance structures over variance components method, which assumes constant variances and correlations throughout the subjects. However, specifying random model matrices and covariance structures in the $\mathrm{R}$ matrix did not have an advantage over an approach where slopes were manually calculated and analyzed as data using ordinary least squares because they both had similar results. Correlations among covariance parameters were high in the first weeks while decreasing greatly after the very first week, indicating that simple covariance structures may lack the necessary power to give correct inferences. However, different approaches that do not use covariance structures may still be useful. In this study, rank of the major groups stayed the same whether it was slopes analysis or the ante-dependence method.

\section{Conclusions}

Heavy or over-conditioned kids (high BMI) were affected more severely from weaning stress compared to light or low BMI kids. Overfeeding kids until weaning may waste valuable milk in dairy goats. Male kids may be more resistant to the stress of weaning. Ten kg live weight at weaning may be reasonable in Saanen kids. There is a minimum age/weight level for weaning and the time to wean the animals depends on the economics of a particular enterprise (NAGPAL et al., 1995). Using covariance structures to analyze repeated data does not seem to be changing ranks of weight or gender groups compared to the method where slopes are calculated manually and analyzed using a diagonal matrix of the ordinary least-squares null model.

AKAIKE, $\mathrm{H}$ :

\section{References}

A New Look at the Statistical Model Identification, IEEE Transaction on Automatic Control, AC -19 (1974), $716-723$

BRAMELD, J.M.; FAHEY, A.J.; LANGLEY-EVANS, S.C; BUTTERY, P.J.:

Nutritional and hormonal control of muscle growth and fat deposition. Arch. Tierz., Dummerstorf 46 (2003), Special Issue, 143-156

EVERITT, B.S.:

The Analysis of Repeated Measures: A Practical Review with Examples. The Statistician, 44 (1995), $113-135$

FEHR, P.M.; SAUVANT, D.:

Production de chevreaux lourds. I. Influence de I'age et du mode de sevrage sur les performances des chevreaux abbatus a 26, 5-29 kg. Annales de Zootechnie, 25 (1976), 243-257

JENNRICH, R.I.; SCHLUCHTER, M.D.:

Unbalanced Repeated-Measures Models with Structured Covariance Matrices, Biometrics, 42 (1986), $805-820$

KENWARD, M.G.:

A Method for Comparing Profiles of Repeated Measurements. Applied Statistics, 36 (1987), 296 -308

LEBBIE, S.H.B.:

Goats under household conditions. Small Ruminant Research. 51 (2004), 131-136

MACCHIAVELLI, R.E.; ARNOLD, S.F.:

Variable Order Ante-Dependence Models, Communications in Statistics - Theory and Methods, 23 (1994), 2683 -2699

MORAND-FEHR, P.; HERVEIEU, J.; BAS, P.; SAUVANT, D.:

Feeding of young goats. Proceeedings of the third international conference on goat production and disease, (1982) Tucson, Arizona/USA

NAGPAL, A.K.; SINGH, D.; PRASAD, V.S.S.; JAIN, P.C.: 
Effect of Weaning Age and Feeding System on Growth Performance and Carcass Traits of Male Kids in 3 Breeds in India. Small Ruminant Research, 17 (1995), 45-50

PALMA, J.M.; GALINA, M.A.:

Effect of early and late weaning on the growth of female kids. Small Ruminant Research. 18 (1995), 33-38

PATEL, H.I.:

Analysis of Incomplete Data from a Clinical Trial with Repeated Measurements, Biometrika, 78 (1991), $609-619$

RINGDORFER, F.:

The effect of genotype, sex and final weight on slaughter performance of kids. Arch. Tierz., Dummerstorf 44 (2001) Special Issue, 385-390

SAMPELAYO, M.R.S.; ALLEGRETTI, L.; EXTREMERA, E.G.; BOZA, J.:

Growth, body composition and energy utilisation in pre-ruminant goat kids - Effect of dry matter concentration in the milk replacer and animal age. Small Ruminant Research. 49 (2003), 61-67

SAS $\AA$ :

SAS Institute Inc., SAS OnlineDoc®, Version 8, Cary, NC, USA, (1999)

SCHWARZ, G.:

Estimating the Dimension of a Model, Annals of Statistics, 6 (1978), 461 -464

SNELL, F.; TAWFIK, E.S.:

Nutrient Consumption and Body Mass Development of Suckling Goat Kids of the Production Genotypes of Milk, Meat and Fibre. (1999) Proc. 50th Annual Meeting of EAAP, Zürich

STEINHARDT, M.; THIELSCHER, H.H.:

Milk Ingestion and Growth Performance of Suckler Calves Born During Winter Stalling From German Red and White Breed and From Old Type German Black and White Breed in a Cow-Calf Operation. Arch. Tierz., Dummerstorf 47 (2004), 47-58

TOUKOUROU, Y.; PETERS, K.:

Impact of feed restriction on the growth performance of goat kids (German language). Arch. Tierz., Dummerstorf 42 (1999) 3, 281-293

UGUR, F.; SAVAS, T.; DOSAY, M.; KARABAYIR, A.; ATASOGLU, C.:

Growth and Behavioral Traits of Turkish Saanen Kids Weaned at 45 and 60 days. Small Ruminant Research, 52 (2004), 179-184

WOLFINGER, R.D.:

Heterogeneous Variance- Covariance Structures for Repeated Measures, Journal of Agricultural, Biological, and Environmental Statistics, 1 (1996), 205-230

YAN, T.; COOK, J.E.; GIBB, M.J.; IVINGS, W.E.; TREACHER, T.T.:

The Effects of Quantity and Duration of Milk Feeding on the Intake of Concentrates and Growth of Castrated Male Saanen Kids to Slaughter. Animal Production, 56 (1993), 327-332

\author{
Received: 2004-06-04 \\ Accepted: 2005-03-09 \\ Authors' addresses \\ Yrd. Doç. Dr. AKIN PALA, Doç. Dr. TÜRKER SAVAŞ, \\ Doç. Dr. FEYZİ UĞUR, Araş. Gör. GÜRBÜZ DAŞ \\ Çanakkale Onsekiz Mart Universitesi, \\ Ziraat Fakültesi, \\ Zootekni Bölümü, \\ TR-17100, Canakkale, Turkey \\ E-mail: akin@comu.edu.tr
}

